\title{
From the Library to the Lab: Close Reading Rabbits as a Cross-Disciplinary Experiment
}

\author{
Jameson KISMET BELL' 10
}

'Dr., Bogazici University, Department of Western Languages and Literatures, Istanbul, Turkey

ORCID: J.K.B. 0000-0003-1488-599X

\section{Corresponding author: \\ Jameson KISMET BELL, \\ Bogazici University, Department of Western Languages and Literatures, \\ Istanbul, Turkey \\ E-mail: j.kismetbell@boun.edu.tr}

Submitted: 04.09 .2019

Accepted: 25.10 .2019

Citation: Kısmet-Bell, J. (2019). From the library to the lab: Close reading rabbits as a cross disciplinary experiment. Alman Dilive Edebiyatı Dergisi - Studien zur deutschen Sprache und Literatur, 42, 1-17. https://doi.org/10.26650/sds|2019-0014

\section{ABSTRACT (ENGLISH)}

This article situates the practice of close reading within a cross-disciplinary context that moves beyond literary criticism and linguistic analysis to sociology and the history of science. A comparative approach to the practice of close reading adds to the toolbox of literary critics, who often focus on meaning rather than material. After a review of close reading from a literary point of view, I introduce Latour and Woolgar's (1986) concept of microprocessing and Rheinberger's (1997) concept of pragmatogony as equally valid forms of close reading from the disciplines of sociology and history of science. If a combination of these techniques can be applied to literary works, literary critics can analyze the epistemic value of literature, which requires experimentation with the material of a literary artefact, which in turn affects the author and critic. Through examples of engaging literary material in addition to representations, literary critics can experiment with and redefine the literary object as an epistemic object and the practice of close reading as undefined at the time of creation and interpretation. By way of metaphors and folklore about rabbits, a novel with a white rabbit, and genetically modified rabbits, this article offers three conclusions that appear when the practices of microprocessing and pragmatogony are applied to literary works. The reconceptualization of the practice of close reading, 1) transforms the author and reader into hybrid scientists-artists, rather than prophets, geniuses, or intellectuals; 2 ) transforms the literary object of study from a book to any material object; and 3) transports the practice of close reading from the library to the laboratory.

Keywords: Close reading, literary criticism, rabbits, history of science, sociology 


\section{Introduction}

Lab Technician. AGCT. Poem. Rabbit. GFP Protein.

This incomplete list comprises a category of material objects and actors that can be read "closely." Depending on one's discipline, one may recognize the terms above and the concept of "close reading" may signify a lot or little. For literary critics, close reading is a particular practice from the early and mid-twentieth century that developed a habit of paying more attention to the words of the work, focusing longer on the words of a work, and moving beyond a commonsense understanding to a deeper meaning of the words of a work. Close reading is a collection of adverbs to designate a special type of reading of author-created words. By "author-created,"I mean a work that is somehow distinctive and intentional, rather than words that are off-the-cuff or commonplace.

Outside of literature departments, close reading may signify nothing at all because the concept and practice does not go by that name. This does not mean there is no close reading outside of literary criticism. Except for the word "Poem," not much on the list is traditionally "literary." A lab technician, GFP protein, rabbit, and amino acids AGCT that make up DNA sequences would not be traditional objects for literary critics to read closely. Yet, as the list above demonstrates and I will show in due time, there are vibrant discourses in the history of science and sociology that use similar adverbs when engaging objects of study. It is my attempt to introduce literary critics to these concepts that often overlap with close reading.

In order to reach this goal, I imagine the audience of this article to be literary and/or cultural critics, though others outside of these disciplines might be interested in the discussion of various forms of close reading. This article will attempt to situate close reading in a cross-disciplinary conversation that points beyond literary criticism and linguistic analysis. My interest in non-literary forms of close reading developed out of my previous book, which used techniques of close reading from literary criticism to analyze what would not traditionally have been considered "literary objects." I read visual and verbal representations of the brain in early sixteenth century medical and surgical books to reveal an unknown object to historical discourses (Kısmet Bell, 2018). Conversely, this article will attempt to bring concepts and practices of microprocessing and pragmatogony to literary criticism from outside the discipline. A comparative approach to the practice of close reading will hopefully add substance - the material object and practices - to 
literary close reading that is often focused on the past, rather than experimenting with the future. In the next section, l'll offer a brief history of close reading that reveals places where expertise from other disciplines may supplement well-known approaches to literary artefacts.

I will conclude with examples of close reading rabbits, which should offer a means by which literary critics can apply these scientific concepts to literary works. My choice of representations of rabbits as an example of a comparative technique of close reading is both arbitrary and intentional: it is arbitrary because, if microprocessing and pragmatogony are useful techniques for literary critics, one could apply them to the material of any literary representation. Rabbits, chairs, dogs, books, and poems would each allow for critics to engage the material of representations, rather than just the representation itself. Rabbits are also intentional because of the over 2,000-year history of domestication (DeMello, 2012, p. 86). We are familiar with rabbits as pets, food, clothing, laboratory animals, and literary and cinematic representations. If we can't close read rabbits, we can't close read anything.

\section{Close Reading Inside and Outside of Literary Contexts}

As we begin this journey into close reading, it is important to pay attention to the goal, which is a comparison of close reading practices inside and outside of university literature departments. I first want to offer a brief history of close reading from a literary perspective that follows four basic stages, the fourth of which is now being questioned: 1) Close reading as exegesis; 2 ) Close reading as moral education; 3) Close reading as a special and isolated activity; and 4) Close reading beyond the book. This brief history will allow us to see that microprocessing and pragmatogony have their points of contact and divergence, particularly in relation to the objects of study and the methods by which we analyze objects. As literary critics, we must first ask ourselves two important questions: what is "close reading?" and what are the objects of inquiry for this particular methodology? Answers to these questions will lead to a need for other methods of analysis and objects of study.

As a contemporary style of reading and interpreting poetry, short stories, and occasionally novels or other "literary" works, close reading began as an ancient practice of interpreting sacred texts. This process was popular in the Middle Ages under a different name: exegesis of human language that concealed divine origins. The practice of 
interpreting religious texts as prophetic speech then spread to the creation and interpretation of secular works as well, which lasted well into the Early Modern Period. Liberal humanism in the late eighteenth and nineteenth centuries introduced the second stage of close reading by shifting the emphasis away from a divine source of inspiration to the moral education of citizens rather than the salvation of souls. Authors and critics appeared as geniuses and intellectuals rather than divinely inspired media.

The third stage appeared in the early twentieth century through the pedagogical methods of what was called "New Criticism," which positioned itself against the moralsecular literary criticism combined with history. These New Critics saw themselves as part of a so-called "modernization" of literary studies, which meant educating a new type of student. Though there is a large gap between the Middle Ages and the twentieth century, we find that in the intervening centuries, close reading had become a secular mode of education outside of religious contexts. Ethics began and ended with the education of the individual, who required instruction in a particular style of engaging the world. Close reading, in its early twentieth century form, reacted against this trend of set answers, moral sentiments, and formulaic perceptions of the world, including literature.

Cleanth Brooks and John Crowe Ransom, the best-known literary critics from this period, limited close reading to great works for the sake of the development of the reader and the continuation of the discipline. For both Brooks and Ransom, a poem is action; it is doing something that students and critics must follow, what Brooks named "the meanderings of a good poem" (Brooks, 1947, p. 208). Close reading began and ended with a reader and a work through an analysis of the work's formal features, which implied a criticism of the opinions or dogmas the reader brought to a work through stock responses that distorted the figurative language. Without a critique of the process of reading, the reader would transform the poem into something that it was not.

In addition to more rigorous methods, Ransom and Brooks offered limitations on objects of study, excluding some works as not poetic. We see that the selection process deemed some works as not deserving of interpretation, while others became canonical and were repeatedly reinterpreted. Brooks goes so far as to categorize most of the poems he interprets as part of "the central stream of tradition" (p. 192). Unwittingly, these New Critics were justifying the literary history they so much wanted to rid from their classrooms. From this point of view, if one is to spend a lot of time reading poems closely, they should be great works. 
The fourth stage and it's conclusion has led to the present moment in literary criticism, spanning the 1960s to 1990s, where one finds the influences on close reading of deconstruction, feminism and gender studies, Marxism, psychoanalysis, cultural studies, and literary pedagogy (Felski, 2015). These cultural domains also expanded that which was considered worthy of close reading: the shift in what is worthy of close reading brought a radical shift in the practice of close reading itself. Mark Johnson and George Lakoff mark the category of "great literature" as one that is based on the belief in separate literal and figurative language forms (Lakoff \& Johnson, 1980). Poetry and literature came out of great rhetoric and became the domain of "great" writing, which emphasizes a special form of the linguistic code and authors who mastered this code. Great works make the codes of language more special, more unique. However, if this distinction between literal and figurative language forms is artificial — or if all language is figurative - then the objects of study multiplies. One need not only study great works to study figurative language.

What remained unquestioned until recently in the close reading of literary works is the "book" quality of literature. Poems belong in anthologies or books. Short stories are collected in books, novels are books, the material of the literary artefact is paper and ink, and the home of these books is the library. When Hayles (2004, p. 68) wrote that we have been "lulled into somnolence by five hundred years of print," she was attempting to help literary critics "wake up to the importance of media-specific analysis." Unaware or at least finding it unimportant, early New Critics paid little attention to the material by which literature was created. The content of literature was the focus of pedagogy: of course literature came in books.

In this emerging stage of literary close reading, we may take it for granted that books are things; poems are things; writing or inscribing is an action upon a thing. These literary objects and practices are material in the same way the genome, a tree, a rabbit, or scientist are material. But these are not stable things. After Barthes' (1977) and Derrida (1982) shifted the focus away from the author and the individual work, we witness a slow turn to other objects that can be close read, which in turn has redefined what it means for an object to be literary. Dolphijn and van der Tuin (2013, p. 108) and Hayles (2004, p. 69) among others, explore the possibilities of "New Materialism" that has emphasized "materiality-in-change." In the close reading of a material object, both the subject and the object encounter a transformation. As we will see through a comparison of close reading practices in the next section, artists are as much scientists as scientists are artists. This juxtaposition of science and art follows recent work on the artistic dimensions of scientific 
practices and the scientific dimensions of artistic practices from Crispin and Gilmore (2014). The production and interpretation of a poem follows similar epistemic paths to viewing a neuron under a microscope, or scribbling a note during a laboratory experiment: these inscriptions are products of epistemic activities, the domain of which must be delimited - i.e. the laboratory - to judge the value of knowledge produced.

It is in this post-structuralist moment where the tension between the linguistic and semiotic codes comes to the fore. No longer readers in the "New Critical" sense - adding semiotics to criticism allows for reading all objects as signs - the formal and rhetorical techniques of early twentieth-century literary criticism are no longer limited to mainstream literature or great works. Rather than emphasize the communicative value of the linguistic code - through paraphrase, generalization, or translation of one form into another - sign-based close readers focus on the material object as it wavers between the specific and the general, the signifier and the signified that coalesce into a sign.

In this brief and inadequate history of literary close reading, we begin to see points of contact with sociology as well as history of science in the shift away from linguistic codes to semiotic codes. Since the turn of the millennium, Jane Gallop (2000), and more recently Felski (2015), have offered limitations to the practice of close literary criticism, as well as the advantages literary critics can offer through an analysis of literary and non-literary works. Whereas Gallop defines close reading as a means to save the discipline of literary criticism from oblivion, Felski's approach is less histrionic, delimiting the edges of the influence of critique, where it functions, and where it fails. Felski offers the suggestion that, "different methods are needed for the many aims of criticism, and there is no onesize-fits-all form of thinking that can fulfill all these aims simultaneously" (p. 17).

Following this statement, there is no singular "close reading" and introducing literary critics to the many forms of criticism outside of the domain of literature is partly the aim of the next section of this article. With these points in mind, we can now compare these key elements with two non-literary forms of close reading.

\section{Microprocessing and Pragmatogony}

The shift away from linguistic codes, or the addition of semiotic codes to the interpretation of literary works, is particular to literary criticism. Other disciplines did not have to leave language behind to find the sign. They started with the sign. For example, 
the sociologist Steven Woolgar and historian of science Bruno Latour teamed up to focus on the details of laboratory life - the everyday conversations, equipment, people, and acts of inscribing that participate in the production of facts. They call their own method of analysis a form of microprocessing that includes the rational and the irrational that appears when one "closely examine(s) the day-to-day operations of the laboratory, not the grand theories, but the microprocesses by and on which these theories are based" ( $p$. 151). Whether it's a brain peptide or the notes, gestures, and routines of lab technicians, the practice of paying attention to that which is outside of the rationally constructed narrative of the final product reveals the illogical, situated negotiations by which scientists work. Latour (1987, p. 255) proposes we do away with cognitive explanations or interpretations and instead focus on the micro-techniques by and through which knowledge is produced, both on small and large scales.

Philosopher and historian of science, Hans-Jörg Rheinberger sees scientific activity as experimental and historically situated, which requires a pragmatogony (pragma-thing, matter; gonos-the created), or a type of historical analysis that includes the process of something becoming known which, at the time, was not yet known (1997, p. 16-17). Whether it's a protein in a test tube or correspondences between multinational laboratories, scientists do not know the future. They are in the practice of creating it. However, they have inherited particular technologies, habits, and spaces within which they work, which cannot be directly linked with future knowledge or discoveries. Future knowledge appears through experimentation with epistemic objects within an experimental system.

Literary artefacts such as poetry, novels, graffiti, or genetic code should be treated as epistemic objects. In relation to these objects, any form of close reading needs to be appear as experimentation. What is this epistemic object a literary work is supposed to be and what is experimentation in relation to reading these objects? Rheinberger defines such an object in relation to the discovery or creation of new areas of research and the subsequent replacement of previous systems out of which epistemic things arise: "Most new epistemic things take their shape from old tools" (1997, p. 81). An epistemic object, for Rheinberger, is synonymous with Foucault's (1972, pp.139) discourse-object, or the embodiment of a concept. Epistemic objects are ideograms, where the difference between the old and the new arises from the accumulation of experience, or how humans begin to conceptualize material within a historical network of signification. Until a certain level of experience has been obtained, the new is indecipherable because it cannot be represented. 
Knowledge only appears when it is "embedded" within this semiotic text. Embedded cognition presupposes a continuity between the material world and the one thinking about and through the material world, a continuity that blurs if not obliterates the divide between the self and the other, the author and the reader, the mind and the brain, or the inside and the outside of historical periods (Clark \& Chalmers, 1998). Inasmuch as the subject uses the elements of the environment as tools, these very same tools shape the cognitive processes of their very use. The epistemic object is that which appears through this experimental process.

If a poem is a "meandering movement," as Brooks claims, then like all other instruments, it is an embedded tool. How one imagines its functioning is historically situated, requiring the reader to pay attention to the context out of which the object appears. And, if a reader follows this meandering movement of a literary object, one is unsure about the state of the object until after one has engaged the object. Within an experimental system, an object is not-yet-defined at the moment of engagement and the interaction of reader and object is by definition, experimental. Any other form of "close reading" would simply recognize formulas, patterns, and familiar codes, or situate the object within the domain of the text.

Though it may seem strange for literary critics to think of the domain of their practice as a "laboratory," or authors as "scientists," these concepts need not be so foreign. Rheinberger describes the production of representations in the laboratory, a space created out of nineteenth-century national, social, and epistemological concerns. He prefers to call the laboratory an experimental system, or the set of nebulous rules, habits, and technologies that one uses "somewhere" (1997, pp. 19-20). Hagner expands this definition so that "a laboratory is where you find it" $(2012,244)$. Epistemic things are produced both on grand scales as well as within the unexciting scribbles of a notebook, photographs from a mahogany-and-brass folding camera, and stories told to a motley group of adults and children. Experimental systems need not be limited to a particular age, a particular discipline, or particular space. Literary critics who experiment with close reading objects in the production of the future can offer a narrative of the production of the object, not just an interpretation of the object itself.

Before we transition to the next section, it may be useful to take stock of where we've come. Each of these interpretive activities take place at the level of details, which are themselves situated within socio-cultural arrangements. Despite their differences, microprocessing and pragmatogony emphasize the following common traits of a detailed analysis of cultural objects and practices: 
1) the embeddedness of the observer in relation to the observed

2) the bundling, weaving, or texting of objects within a historical a priori

3) the inclusion of a description that accounts for the emergence from what is unknown to what is known as experimental, or not-yet-defined (Kısmet Bell, 2018)

\section{Epistemic Objects and Experimentation: Rabbit Folklore, Alice's Adventures in Wonderland, and Alba}

After this long exposition of the history of close reading and introduction of new concepts of microprocessing and pragmatogony to the literary critical toolbox, it is time to introduce the epistemic object of our study: the rabbit. Though I cannot offer close readings in detail in this short space, I can gesture toward what an experimental close reading would look like. Rabbits appear in folklore, which would be traditionally excluded from close reading; Rabbits also appear in "great" literary works, such as Lewis Carroll's (1865) Alice's Adventures in Wonderland, which has been included in the literary canon of Victorian children's literature as well as taught in schools for a century. It has become part of English-language cultural consciousness. Rabbits also appear as genetically modified organisms such as Alba, a green rabbit created in a laboratory in 2001. To completely define this "rabbit" concept in relation to a material object is impossible, yet we can delimit the contours of how this object came to be part of the dynamic of human literary representations.

Let us first start with rabbits in folklore, which is traditionally the domain of speech. Whether one is hearing or reading The Tarbaby and the Rabbit, native American trickster tales with a motif of rabbits outside of society, clever, helper or courageous, oral representations of these animals assume the embeddedness of the observer in relation to the observed. Rabbits in folklore are represented as liminal creatures, having already become domestic as well as retaining their "wild" characteristics. The history of these animals is intertwined and woven into the history of humans. These tales can be etiological and tropological, like the Sioux Legend of "How the Rabbit lost its tail." A close reading of any of these tales would have to include an account of the emergence of what is known from what is unknown. In oral cultures, life, geography, weather, and human and animal interaction coalesce into an immense laboratory for experimentation. The tale itself - the oral representation - is a mark of this process of becoming of the rabbit and humans together. The experimental system, the space of the production of the subject and object, is a fragment of what we call culture. 
In graphic cultures, the material of representation is outside of the body, thus extending one's memory to the scroll or codex. An example of the rabbit in written form appears in the medieval German writer Wolfram von Eschenbach's Parzival (11701220), where he describes his own thoughts that "zig-zag like a running rabbit" (Eschenbach, 2008 version, p. 229). Rather than devolve into a collection of rabbit motifs, we can conduct a pragmatogony that assumes the content of the Parzival book was not yet complete at the time of telling or writing the romance. The concept of the rabbit's fast and changing movement metaphorically stands in for the author's own ability to represent orally and graphically. Rather than a domestic rabbit used for fur and food, Eschenbach utilizes the concept of a wild hare, unrestricted by society, to define the episodic structure of oral poetry. Both the rabbit and his thoughts need discipline.

Here it is not the content of the story of Parzival that is important, even though the iambic trimeter and short rhyming couplets are part of an oral tradition, but the material and form of the book as it comes into being. Whereas speech zig-zags between topics through metaphor and comparison, writing an extended romance like Parzival must be disciplined, sequential, and logically ordered with the tools of a pen, knife, and animal skin, just as Eschenbach's titular character Parzival says, "Like Parchment I was, black and white of equal degree" (Eschenbach, 2008 version, p. 229). In graphic cultures, the laboratory narrows to include a writer, parchment, and ink by which thoughts become ordered and tamed. We begin to see specialization of tasks, routines, as well as diverse personas that appear. These characters can utilize tools in specific ways when they are present and become different characters when the tools are gone. The manuscript Parzival, the final product of this experimental system, if the micro-techniques out of which it arose are to be read closely, should be read as embedded in the semiotic codes of this bio-technological milieu.

In the sixteenth century, we find the rabbit motif again in medical literature. In his Mirror of Medicine, the German author Lorenz Fries uses the rabbit to symbolize food as well as disordered thought when he writes a short parable of good perception,

There was once a Lord from Strassburg who purchased as many little birds as there were birds to sell at the fish market. He gave these birds to his cook that he should prepare them. The cook, however, went and bought a special rabbit, and cooked it instead (Fries, 1518, p. 20-21). 
As a metaphor for the transition from writing to print, Fries uses the image of birds to stand in for all sensible experience and the rabbit to stand in for a single concept of this experience. The Lord and cook are represented as characters by which the reader understands a disciplined doctor who can recognize all the diversity of experience (the birds) and the untrained cook, who only sees a rabbit. In addition to the common trope for a cook in the late Middle Ages as a simpleton or fool, the association with rabbit and food is clear, both for the body and the mind. This reference also shifts the contours of the laboratory even further, adding more tools, techniques, and knowledge one must have to engage and represent the complete domestication of rabbits. The author, a medical doctor, is also experimenting with the medium of print technologies - printing the first German translation of medieval Latin medicine - and he views the product of his labour as anything but common, or anything but a rabbit. He had no idea the effect his book would have, which was reprinted over eight times in the sixteenth century alone.

If we jump ahead, we find Lewis Carroll, a nineteenth century children's author writing about the now well-known white rabbit. Charles Lutwidge Dodgson, prior to taking the pen name Lewis Carroll, was a mathematician, clergyman, photographer, and amateur botanist and zoologist, collecting and studying wild animals in nearby Cheshire (Winchester, 2001, p. 26). If we take the first point of a scientific close reading - the embeddedness of the observer in relation to the observed - we cannot focus on the book as a given material object. Over the last 150 years, Alice's Adventures in Wonderland has appeared in various editions with various illustrations to make "the book" a nonentity.

Each moment in the inception history of the object redefines the object itself: from oral stories, to the first hand-written manuscript Alice's Adventures Underground that were illustrated by Dodgson himself in 1864, through the first printed edition with woodcut images by the professional Illustrator Sir John Tenniel, to a radio broadcast in 1937, multiple cinematic adaptations, and hundreds of reprints, makes the object itself impossible to completely delimit. Latour demonstrates how a historian or sociologist uses microprocessing to approach the action of scientists, not the objects of science, such that "the new object, at the time of its inception, is still undefined. [At] the time of its emergence, you cannot do better than explain what the new object is by repeating the list of its constitutive actions. [The proof] is that if you add an item to the list you redefine the object, that is, you give it a new shape" (1990b, p. 64). If literary critics take this process seriously, we would see what Katheryn Hayles (2004) describes as the difference between 
literature written with a pen, printed in a book, or composed on a computer; or what Bruce Holsinger (2009) describes as the difference between a medieval manuscript created on parchment or paper, animal skins or stone; or what Bornstein (1999) calls "material textuality" in his analysis of the same sonnet form that is spoken, printed in a book, circulated in a magazine, or stamped in bronze.

As an epistemic object, the book Lewis Carroll created was a representation of oral stories told on a series of boat journeys with Alice Liddel, a young girl from a neighboring family. Rather than close reading the finished product, we must look to the material conditions, if available, by which the product became what it was, or the inclusion of a description that accounts for the emergence of what is unknown to what is known as experimental, or not-yet-defined. The contours of the experimental system in which Carroll worked has been outlined by Winchester (2001) to include people with their explicit and implicit desires, objects, and spaces not traditionally referenced in a literary close reading.

If we shift from a fictional representation of Alice and the white rabbit, we can see the creation of a "real-fiction" rabbit called Alba or "GFP Bunny." Alba was created in the year 2000 when transgenic Brazilian artist Eduardo Kac and French geneticist Louis-Marie Houdebine collaborated to create the new hybrid life form combining genetic fragments of a gene found in the Aequorea Victoria jellyfish into an albino rabbit's genetic sequence. As an epistemic object, Alba reveals changing human relationships to representation, media, and materiality, not to mention ethics, life, technology, commercialism, globalism, and our media-influenced imagination. An object that did not exist in nature is produced in a laboratory with a liminal existence. It is a material object that is both a representation and a performance.

What we see with Eduardo Kac and Alba is the shifting of the experiment from inside to outside the traditional laboratory, from the controlled, sterile, mechanical, electrical, and national space to the rest of the world through mass media. Kac asks, what happens when we shift the space of the scientific ritual outside of the lab? He then lists nine goals of the "GFP Bunny/aka Alba" experiment, two of which he calls, "an ongoing dialogue between professionals of several disciplines (art, science, philosophy, law, communications, literature, social sciences) and the public on cultural and ethical implications of genetic engineering" and "integration and presentation of 'GFP Bunny' in a social and interactive context" (Kac, 2000, p. 8-9). 
By putting Alba in the public sphere, Kac draws attention to the experimental structure of culture itself. Unlike domestic breeding and animal husbandry referenced in ancient cultures and continued in genetically modified organisms meant for reproduction today (plants and animals for consumption), adding a "green fluorescent protein" to Alba's genetic code makes it a singular animal not meant for reproduction. Alba was rewritten in the sense of its genetic code being fragmented and combined with the genetic code of another animal, Aequorea Victoria jellyfish. However, this "rewriting" of the genetic code draws attention to the fact that Alba's genetic code had already been rewritten hundreds, if not thousands of times over the centuries. Lewis Carroll's white rabbit from Alice in Wonderland reveals the cultural fascination with albino rabbits and the great lengths Europeans and non-Europeans went to control the appearance of domestic animals. As an albino, Alba had no skin pigment and under ordinary environmental conditions would be completely white with pink eyes. Nineteenth century animal husbandry, as well as representations of these anthropomorphic creations, offered an unknown future for the albino rabbit as part of both popular and scientific milieus.

The albino rabbit, for example, is a natural (recessive) mutation which in the wild has minimal chances of survival (due to lack of proper pigmentation for camouflage and keener vision to spot prey). They are visible so they are eaten. However, because they have been bred by humans, albino rabbits can be found widely today in healthy populations. The human preservation of albino animals is also connected to ancient cultural traditions: almost every Native American tribe believed that albino animals had particular spiritual significance and had strict rules to protect them (Kac, 2000, p. 129130).

Even before the Alba experiment, white rabbits had become the embodiment of humanity's role in selective evolution, what Walter Ong calls "the artificiality that is natural to humans" (1982, p. 81). By shortening the time of this genetic mutation - and controlling the results - Kac brings Bruno Latour's theory of microprocessing to a public discussion through the detailed catalogue listing how the rabbit was created in the laboratory that is a spatially and temporally reduced frame for human culture. If our bodies are already inscribed with the genetic history of life, literary representations are artefacts of this process of becoming that is not-yet-known. Laboratory scientists are also cloning mice, rabbits, and other laboratory animals in order to ensure that the animals used in research are genetically identical and to control for any "imperfections." (Demello, 
2012, p. 92). Close reading as a pragmatogony focuses on the detailed process of how these literary objects represent as well as project a genetic past into a genetic future. Literary representation, whether with pen, paper, ink, typewriter, computer, or now our genetic code, is the practice of inscribing bodies with codes based on our current media embodiments, which are limited to the technologies and imagination of the present. Literature cannot represent the future. However, it can embody it.

Alba also embodies what Latour calls the deflationary/inflationary binary of inscriptions he calls immutible mobiles: there is a push of all inscriptions to become ever smaller while at the same time these small inscriptions have ever larger effects (Latour, 1988 , p. 3-5). Phenotypical changes in rabbits (albinism) that appear randomly in nature for thousands of years, had quickened in the nineteenth century with selective breeding in captivity, and can now be done in a few weeks in the laboratory. What's more, since inscriptions are immutable and mobile, they can be fragmented and recombined in once unimaginable ways. No longer are we dealing with the fragmentation of diverse linguistic codes and their recombination into a new form of literature, but we are dealing with the fragmentation and recombination of diverse genetic codes into a new form of life done at a previously unimaginable speed with not-yet imaginable consequences.

Oral and written literature, as a practice of representation with linguistic codes, represents a cross section of the world that is only 4-5,000 years old. Such a "snapshot" shows a very limited view of a world that has been around for billions of years and will (potentially) continue for billions of more years. Tamasula (2002) showed the influence of science on art, that artists are no longer dealing with external media of speech, writing, or mechanical and electrical technologies, but with the very codes of life itself. When Eschenbach or Fries, Carroll or Kac represent a rabbit, they are representing fundamentally different concepts and fundamentally different rabbits. Daston has shown that every scientific object has a biography which must be included in its description (2000). To only describe the final representation is to mistake the now for the real.

Almost twenty years after the Alba experiment, in 2018, the once unthinkable became real: researcher He Jiankui at the Southern University of Science and Technology in Shenzhen, China edited the human genome to create the so-called CRISPR-babies (Cyranoski, 2019). As with the evolution and changing representations of rabbits, the speed at which humans are changing has increased, making any literary representation of humans time-specific, a snapshot of a specific genetic map: we are no longer the humans 
we were and not yet the humans we will become. Like rabbits, humans are epistemic objects, or ideograms that combine matieral and concept. When the concept changes, so does the material. Likewise, when the material practices by which we know ourselves change, so does the concept of "human." Tomasula wrote of the Alba experiment, which applies to humans as well: "That is, all life, be it a tumbler-pigeon, cow, tomato or human, is composed of the same four-letter genetic alphabet: the chemical bases adenine, guanine, cytosine, and thymine, abbreviated as A, G, C and T. This simple fact means that the genetic manipulation of one species has direct implications for all others" (2002, p. 40).

\section{Conclusion}

Though pragmatogony and microprocessing may be initially unfamiliar to literary critics, I hope that we can agree that the birth of an epistemic object is not, and can never be, the goal of the experiment. The close reading adverbs with which we began this article - longer, beyond, deeper, and more - shift in a pragmatogony and microprocessing because the object itself is no longer the focus. The production of meaning is always a delayed goal of experimental procedures and the final object is only a representation of the final stage of these procedures. A poet may make a poem, but it is never "this" poem that the poet has in mind prior to its creation. It meanders, changes, mutates even, in the course of its production. Like any epistemic object, it first appears as a material artefact through fragmented wanderings within an experimental system. Speech, pen, paper, ink, camera, computer, or genetic code are the material tools by which literary scientists work in her or his cultural laboratory. A close reading or pragmatogony cannot successfully analyze the objects produced within this system because they are unknown at the time of production.

A fruitful approach, which I have briefly and incompletely presented here, is to focus on the micro-processes, equipment, and mundane rituals by which literary objects are produced, circulate, and fade away. This shift in method also shifts the objects of literary study: a green rabbit becomes a literary representation in the same way a fantasy novel, short story, or poem are literary representations: they represent the known through the production of the unknown. To focus on and interpret only the meaning of the object linguistic codes inscribed in speech, on a sheet of paper, or computer screen - misses the wandering paths through which these representations become what, at the time of their production, they have not yet become.

Grant Support: The author received no financial support for this work. 


\section{References}

Barthes, R. (1977). Image, music, text. (S. Heath, Trans.). New York: Hill and Wang.

Bornstein, G. (1999). How to read a page: Modernism and material textuality. Studies in the Literary Imagination, Spring, 29-47.

Brooks, C. (1947). The heresy of paraphrase. In C. Brooks (Ed.), The well-wrought urn: Studies in the structure of poetry (pp. 192-214). New York: Harcourt, Brace and World.

Carroll, L. (1865). Alice's adventures in wonderland. London: MacMillan.

Carroll, L. (1865). Alice's adventures in wonderland. Peter Zelchenko (ed.). Retrieved from https://www.adobe. com/be_en/active-use/pdf/Alice_in_Wonderland.pdf

Clark, A., \& Chalmers, D. (1998). The extended mind. Analysis, 58(1), 7-19.

Crispin, D., \& Gilmore B. (Eds.). (2014). Artistic experimentation in music: An anthology. Leuven: Leuven University Press.

Cyranoski, D. (2019) The CRISPR-baby scandal: what's next for human gene-editing. Nature 566, 440-442. doi: 10.1038/d41586-019-00673-1.

Daston, L. (2000). Biographies of scientific objects. Chicago: University of Chicago Press.

Daston, L., \& Galison, P. (2007). Objectivity. New York: Zone Books.

DeMello, M. (2003). Stories rabbits tell: A natural and cultural history of a misunderstood creature. New York: Lantern Books.

DeMello, M. (2012). Animals and society: An introduction to human-animal studies. New York: Columbia University Press.

Derrida, J. (1982). Différance. Margins of philosophy, (A. Bass, Trans.), (pp. 1-28). Chicago: University of Chicago Press.

Dolphijn R., \& van der Tuin, I. (2013). New materialism: Interviews and cartographies. Ann Arbor: Open University Press.

Eschenbach, W. (2008). Parzival. Frankfurt a/M: Fischer.

Felski, R. (2015). The limits of critique. Chicago: University of Chicago Press.

Foucault, M. (1972). The archaeology of knowledge. New York: Pantheon Books.

Fries, L. (1518). Spiegel der Artzney. Strassburger: Grünninger.

Gallop, J. (Fall, 2000). The ethics of reading: Close encounters. The Journal of Curriculum Theorizing 16(3), 7-17.

Hagner, M. (2012). The electrical excitability of the brain: Toward the emergence of an experiment. Journal of the History of the Neurosciences, (J. Kısmet Bell, Trans.). 21, 237-249. doi: 10.1080/0964704X.2011.595634

Hayles, K. (2004). Print is flat, code is deep. Poetics Today. 25(1), 67-90.

Holsinger, B. (March, 2009). Of pigs and parchment: Medieval studies and the coming of the animal. PMLA, Vol. $124(2), 616-623$.

Kac, E. (2000). Eduardo Kac: Telepresence, biotelematics, and transgenic art, (pp. 101-131). Dobrila, P. T., \& Kostic, A. (eds.). Maribor, Slovenia: Kibla. 
Kısmet Bell, J. (2018). Performing the sixteenth century brain: Beyond word and image inscriptions. Munster: Lit Verlag.

Lakoff, G., \& Johnson, M. (1980). Metaphors we live by. Chicago: University of Chicago Press.

Latour, B. (1988). Visualization and cognition: Drawing things together. Knowledge and Society Studies in the Sociology of Culture Past and Present, 6, 1-40. doi:10.22394/0869-5377-2017-2-95-151.

Latour, B. (1990b). The force and the reason of experiment. In H. E. LeGrand (Ed.), Experimental inquiries. Dordrecht: Kluwer.

Latour, B., \& Woolgar, S. (1986). Laboratory life: The construction of scientific facts. Cambridge: Princeton University Press.

Ong, W. (1982). Orality and literacy. New York: Routledge.

Rheinberger, H.-J. (1997). Toward a history of epistemic things: Synthesizing proteins in the test tube. Stanford: Stanford University Press.

Richards, I. A. (1930). Practical criticism. Edinburgh: Edinburgh Press.

Tomsula, S. (2002). Genetic art and the aesthetics of biology. Leonardo, 35(2), 137-144. doi: https://www.jstor. org/stable/1577194.

Winchester, S. (2011). The Alice behind wonderland. Oxford: Oxford University Press. 
